\title{
The Biological Bases of Group 2 Pulmonary Hypertension
}

\author{
Ana I. Fernández 1,2,3,4, Raquel Yotti 1,2,3,4 Ana González-Mansilla 1,2,3,4(0, \\ Teresa Mombiela 1,2,3,4, Enrique Gutiérrez-Ibanes 1,2,3,4, Candelas Pérez del Villar 1,2,3,4, \\ Paula Navas-Tejedor 1,2,3,4, Christian Chazo 1,2,3,4, Pablo Martínez-Legazpi 1,2,3,4, \\ Francisco Fernández-Avilés 1,2,3,4 and Javier Bermejo 1,2,3,4,* \\ 1 Department of Cardiology, Hospital General Universitario Gregorio Marañón, 28007 Madrid, Spain; \\ anaferavi@gmail.com (A.I.F.); ryotti@gmail.com (R.Y.); anagmansilla80@gmail.com (A.G.-M.); \\ teresamombiela@gmail.com (T.M.); egutibanes@gmail.com (E.G.-I.); cperezdelvillar@gmail.com (C.P.d.V.); \\ paulanavastejedor@gmail.com (P.N.-T.); christianchazopaz@gmail.com (C.C.); \\ legazpi.pablo@gmail.com (P.M.-L.); faviles@secardiologia.es (F.F.-A.) \\ 2 Instituto de Investigación Sanitaria Gregorio Marañón, 28007 Madrid, Spain \\ 3 Centro de Investigación Biomédica en Red, CIBERCV, Instituto de Salud Carlos III, 28026 Madrid, Spain \\ 4 Facultad de Medicine, Universidad Complutense de Madrid, 28007 Madrid, Spain \\ * Correspondence: javier.bermejo@salud.madrid.org; Tel.: +34-91-586-8279
}

Received: 7 November 2019; Accepted: 21 November 2019; Published: 23 November 2019

\begin{abstract}
Pulmonary hypertension $(\mathrm{PH})$ is a potentially fatal condition with a prevalence of around $1 \%$ in the world population and most commonly caused by left heart disease (PH-LHD). Usually, in PH-LHD, the increase of pulmonary pressure is only conditioned by the retrograde transmission of the left atrial pressure. However, in some cases, the long-term retrograde pressure overload may trigger complex and irreversible biomechanical and biological changes in the pulmonary vasculature. This latter clinical entity, designated as combined pre- and post-capillary $\mathrm{PH}$, is associated with very poor outcomes. The underlying mechanisms of this progression are poorly understood, and most of the current knowledge comes from the field of Group 1-PAH. Treatment is also an unsolved issue in patients with PH-LHD. Targeting the molecular pathways that regulate pulmonary hemodynamics and vascular remodeling has provided excellent results in other forms of $\mathrm{PH}$ but has a neutral or detrimental result in patients with PH-LHD. Therefore, a deep and comprehensive biological characterization of PH-LHD is essential to improve the diagnostic and prognostic evaluation of patients and, eventually, identify new therapeutic targets. Ongoing research is aimed at identify candidate genes, variants, non-coding RNAs, and other biomarkers with potential diagnostic and therapeutic implications. In this review, we discuss the state-of-the-art cellular, molecular, genetic, and epigenetic mechanisms potentially involved in PH-LHD. Signaling and effective pathways are particularly emphasized, as well as the current knowledge on -omic biomarkers. Our final aim is to provide readers with the biological foundations on which to ground both clinical and pre-clinical research in the field of PH-LHD.
\end{abstract}

Keywords: pulmonary hypertension group 2; left heart disease; isolated pulmonary hypertension; combined pulmonary hypertension; gene; epigenetics

\section{Introduction}

Pulmonary hypertension (PH) is a major health issue. Although epidemiological studies are still scarce, it is estimated that the annual prevalence of $\mathrm{PH}$ is around $1 \%$ of the world population and is probably increasing [1]. In Western countries, it could reach up to $6 \%$ for subjects over 85 years 
old [1], and it is more frequent in women than men [2]. Understanding the biological foundations of the disease is therefore of major interest.

Pulmonary hypertension is defined by a mean pulmonary artery pressure (mPAP) at rest of $25 \mathrm{~mm} \mathrm{Hg}$ or more, according to established guidelines [3], or $20 \mathrm{~mm} \mathrm{Hg}$ or more, according to reviewed criteria [4]. The multiple conditions that may cause $\mathrm{PH}$ are clustered into five groups [5]. Group 1-PH—also designated pulmonary arterial hypertension (PAH)—accounts for heritable, idiopathic, drug or HIV-related causes among others. Group 3-PH accounts for PH associated with chronic lung diseases, Group 4-PH for pulmonary artery remodeling due to major vessel thromboembolism, whereas Group 5-PH designates a heterogeneous group of multifactorial and unclear mechanisms.

Group 2-PH-PH due to left heart disease (PH-LHD)—designates PH caused by the retrograde transmission of left-atrial (LA) pressure to the pulmonary circulation. This is the source for roughly half of the cases of PH [1]. The diagnosis of PH-LHD is established when LA pressure (or its surrogate, the pulmonary capillary wedge pressure) is above $15 \mathrm{mmHg}$. Atrial pressure overload is caused by either systolic or diastolic left-ventricular dysfunction and/or valvular heart disease (VHD). In most cases of PH-LHD, the increase in pulmonary pressure is purely "passive" and is conditioned by the retrograde transmission of LA pressure-isolated post-capillary PH (iPC-PH). However, in some cases of PH-LHD, complex biomechanical and biological changes take place in the pulmonary vasculature, which may persist even when the left-heart predisposing condition is solved. The hallmark sign of this coexistent pre-capillary component is an increase in the transpulmonary pressure gradient (TPPG, the pressure difference between the mean pulmonary arterial pressure and PCWP) and in the pulmonary vascular resistance (PVR, the TPPG divided by cardiac output). When PVR is $\geq 3$ Wood units, the clinical entity is designated as combined pre and postcapillary PH (cPC-PH) [6]. Differentiating iPCfrom cPC-PH is of major clinical interest because they have a different prognosis and response to treatment $[7,8]$. Furthermore, the finding that patients with cPC-PH may share phenotypic fingerprints with PAH [9] has recently propelled interest in the biological foundations of PH-LHD.

Valvular heart disease (VHD) is a particularly well-suited condition for research in the field of PH-LHD. As opposed to the other causes of PH-LHD, in VHD, the initiating cardiac lesion is amenable to complete hemodynamic restoration. However, the natural history studies of this disease have demonstrated that PH may persist or even develop when the source of retrograde pressure transmission has been corrected [10]. This suggests that impaired molecular and biomechanical pathways sometimes are not re-established once dysregulated for a certain amount of time. However, there is a huge variability in the response of the lung vasculature to the hemodynamic overload and its correction. Unfortunately, the source of such variability is still mostly ununderstood.

All multicentric clinical trials targeting the lung vasculature in PH-LHD have been negative. Investigators recognize that mechanisms of plastic remodeling of the pulmonary circulation in this entity need to be clarified to adequately stratify patient outcomes and successfully identify new therapeutic targets. In the following sections, we review the current state-of-the art biological aspects known to be involved in PH-LHD, emphasizing their potential clinical and therapeutic implications.

\section{The Hemodynamic and Structural Changes of PH-LHD}

The rise in backward pressure at the left atrium and the pulmonary veins is the hemodynamic hallmark of iPC-PH. This upstream pressure transmission has both steady and pulsatile-flow consequences on the pressure of the pulmonary artery, which are only beginning to be understood [11,12]. Vascular tone at this level is regulated by the intimal (endothelial), and medial (vascular smooth muscle) layers and the interlayer interactions, which respond to differentiated stimuli, such as pressure-dependent responses, neural mechanisms, hormonal mechanisms, local metabolic regulations, and endothelial products [13]. The classical paradigm for PH-LHD assumes that longstanding venous hypertension induces structural alterations of the pulmonary arterial bed that characterize cPC-PH [14]. Medial hypertrophy and intimal proliferation of the distal pulmonary arteries and 
arterioles dramatically raise PVR [15]. Interstitial lung edema and alveolar hemorrhage is frequently found, and the vasomotor tone of the pulmonary arteries is also increased. Hypertrophic remodeling of distal pulmonary arteries, fibrosis, and luminal occlusion are likewise common findings in PH-LHD and $\mathrm{PAH}$, but the typical plexiform lesions of $\mathrm{PAH}$ are absent $[16,17]$. As in any type of $\mathrm{PH}$, the increased vascular load leads to right ventricular diastolic dysfunction [18] and afterload mismatch, eventually causing right ventricle dilation, failure, congestive symptoms, and reduced survival [19].

Recent morphological studies are changing this paradigm. A comprehensive analysis of necropsy lung specimens of patients with PH-LHD has identified not only remodeled arterial vessels but also marked thickening of both pulmonary veins and small indeterminate vessels [20]. In fact, the intimal thickening of these vessels was more severe than in arterioles, sharing a similar but milder pattern with primary pulmonary venoocclusive disease. Above all, the hemodynamic severity of $\mathrm{PH}$, as characterized by PVR, correlated best with the intimal thickness of the venous and the indeterminate vessels [20]. These findings challenge the classical hemodynamic compartmentation of the vascular tree and, more importantly, plead for further research on the mechanisms that trigger and sustain intimal thickening in all components of small vasculature of the lung.

\section{The Cellular Bases of PH-LHD}

A retrograde increase in capillary pressure affects the function of pulmonary endothelial cells (ECs) [21]. Capillary injury and subsequent inflammation (Figure 1) induce activation and proliferation responses of fibroblasts/myofibroblast by means of neurohumoral mediators. This results in collagen deposition and thickening of the alveolar septa [22,23]. In parallel to the infiltration of inflammatory cells in the perivascular regions, there is also a thickening of the intima and media of arteries and arterioles, indeterminate vessels, and venules [24,25]. Therefore, ECs seem to be the primary cell type affected by $\mathrm{PH}$, responsible for dysfunctional changes of the endothelium. Beyond the proliferative response, there is also an increased secretion of cytokines and growth factors (e.g., transforming growth factor alpha 1, TGF- $\alpha 1$ ), vascular endothelial growth factor (VEGF), interleukin 1 (IL-1)), an increased production of vasoconstrictors such as endothelin-1, and a decreased generation of vasodilators such as nitric oxide (NO) [26-28]. Damaged ECs also induce recruitment, proliferation, and subsequent differentiation of smooth muscle cells (SMCs). Moreover, the synthetic/proliferative SMCs, which have migrated to the intima, are capable of generating proinflammatory molecules that promote leukocyte infiltration of the arterial wall [28]. Fibroblasts in the pulmonary vascular wall play specific roles in the response to injury, including migration, proliferation, synthesis of intravascular connective tissue, contraction, cytokine production, and, most importantly, trans-differentiation into other types of cells (e.g., SMC) [29]. Inflammatory cells may also play a role in PH-LHD, as suggested by a rodent model of heart failure induced by supravalvular aortic stenosis in which the development of pulmonary fibrosis correlated with the degree of leukocyte infiltration of the lung [22]. 


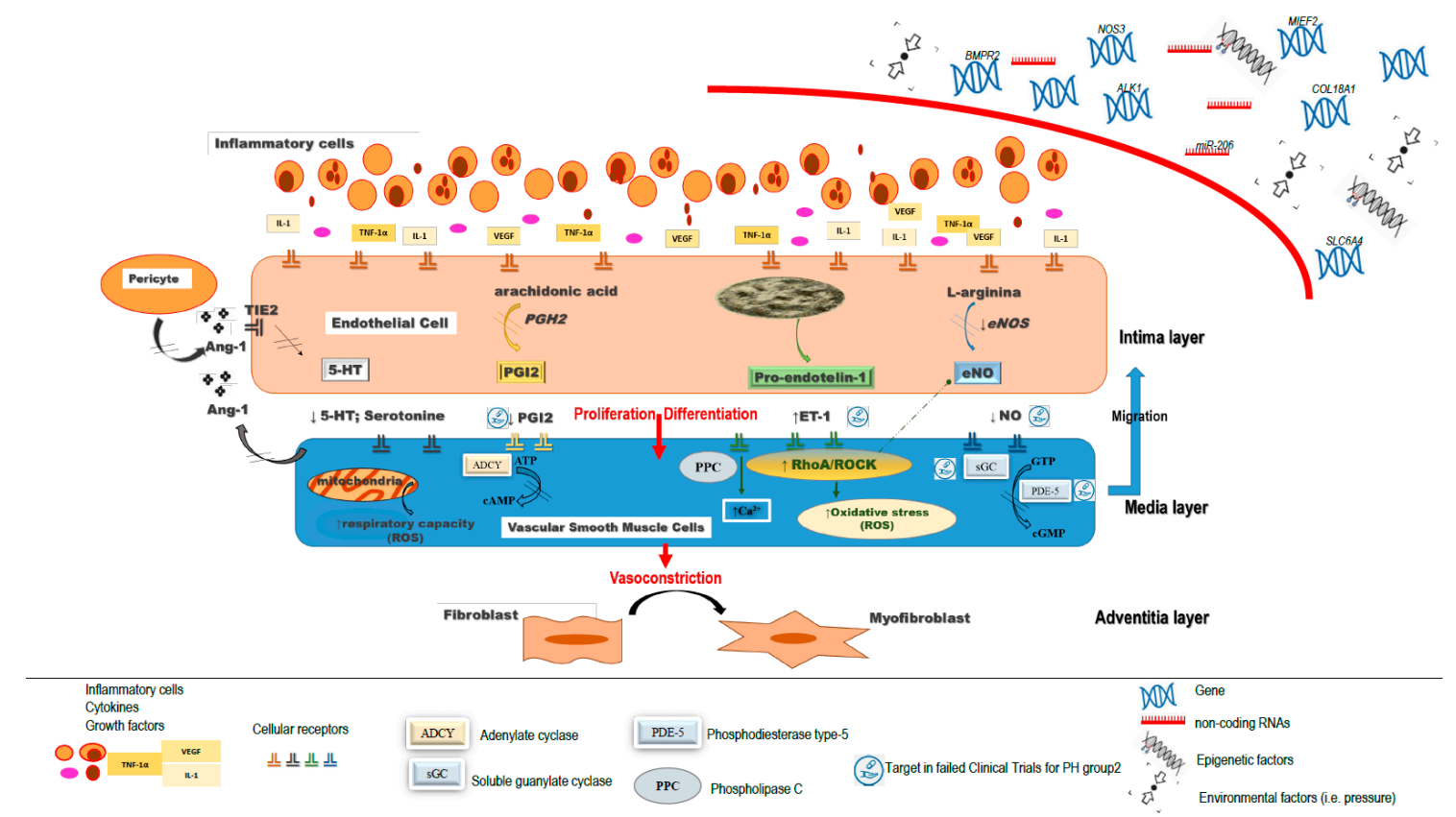

Figure 1. Representation at the vessel wall level of major mechanisms involved in pulmonary hypertension forms with different supportive evidence for left heart disease.

\section{The Molecular Pathways of PH-LHD}

Most of the current knowledge in this field comes from Group 1-PAH and includes endothelial dysfunction, altered mitochondrial function, oxidative metabolism, inflammation, and immune alterations (Figure 1). Some of these mechanisms are presumed to be common among all PH groups, including PH-LHD. Major mechanisms are summarized below, with different supportive evidence for PH-LHD.

\subsection{Endothelial Dysfunction and Endothelial Vasoactive Mediators}

Endothelial dysfunction is caused by the altered production of various endothelial vasoactive mediators. Impairment of the endothelium-derived nitric oxide (eNOS), prostacyclin, angiopoietin-1, and endothelin-1 (ET-1) pathways are involved in all forms of $\mathrm{PH}$ [30].

Endothelium-derived nitric oxide (eNO) is essential for vascular homeostasis [31]. Although the role of eNO in the pathogenesis of $\mathrm{PH}$ remains poorly delineated, it is known that the NO availability is at least partially responsible for reduced pulmonary vasorelaxation. $\mathrm{NO}$ is primarily synthesized in the endothelium from L-arginine and oxygen by the endothelial NO synthase (eNOS, NOS3) triggered by mechanical stimuli or endogenous mediators, such as acetylcholine and bradykinin. NO diffuses to subjacent SMCs. The effects of this gaseous vasodilator are largely exerted by the activation of its molecular receptor, soluble guanylate cyclase (sGC), and the subsequent generation of cGMP through the action of phosphodiesterase type-5 (PDE-5). Hence, reduced L-arginine bioavailability or increased methylarginine production may reduce the production of $\mathrm{NO}$ and directly lead to endothelial dysfunction affecting pulmonary vascular reactivity [32]. Both a decrease of NO production and a reduction of vasodilator responsiveness to NO occur in PH-LHD [33]. However, all multicentric clinical trials in LHD targeted to increase eNO have shown negative or neutral results, whether using inhaled inorganic nitrite [34], PDE-5 inhibitors [35,36], or sGC stimulators [37-39] (Table 1, Figure 1). 
Table 1. Summary of multicentric clinical trials in left heart disease (LHD) patients suffering from pulmonary hypertension $(\mathrm{PH})$.

\begin{tabular}{ccccccc}
\hline Pathway & Drug & N & Condition & PH-Focused & $\begin{array}{c}\text { Main } \\
\text { Finding }\end{array}$ & ACRONYM/Ref \\
\hline eNO & Inorganic Nitrate & 105 & HFpEF & no & neutral & INDIE-HFpEF [34] \\
PGI2 & Epoprostenol & 471 & HFrEF & no & harmful & FIRST [40] \\
PDE-5 & Sildenafil & 216 & HFrEF & no & neutral & RELAX [36] \\
& Sildenafil & 200 & VHD & yes & harmful & SIOVAC [35] \\
sGC & Riociguat & 201 & HFrEF & yes & neutral & LEPHT [37] \\
& Vericiguat & 456 & HFrEF & no & neutral & SOCRATES-REDUCED [38] \\
& Vericiguat & 477 & HFpEF & no & neutral & SOCRATES-PRESERVED [39] \\
& Darusentan & 157 & HFrEF & yes & neutral/harmful & HEAT [41] \\
& Darusentan & 642 & HFrEF & yes & neutral/harmful & EARTH [42] \\
& Bosentan & 369 & HFrEF & yes & harmful & REACH-1 [43] \\
& Bosentan & 87 & HFrEF & yes & neutral/harmful & NA [44] \\
& Bosentan & 1613 & HFrEF & yes & neutral/harmful & ENABLE [45] \\
& Macicentan & 63 & HFrEF \& pEF & no & harmful & MELODY-1 [46] \\
\hline
\end{tabular}

eNO: endothelium-derived nitric oxide; PGI2: prostacyclin; PDE-5: phosphodiesterase type-5; sGC: soluble guanylate cyclase; ET-1: Endothelin-1; HFpEF: heart failure with preserved ejection fraction; HFrEF: heart failure with reduced ejection fraction; PH-focused: whether patients were specifically screened for PH or not.

The prostacyclin (PGI2) is a potent pulmonary vasodilator and platelet antiaggregant. PGI2 is synthesized from cyclooxygenase via the arachidonic pathway in the vascular endothelium and protects against pulmonary vasoconstriction and remodeling in response to various stimuli. For instance, PGI2 overexpression protects mice from chronic hypoxia-induced PH [47]. On the contrary, PGI2 receptor-deficient mice develop severe PH when exposed to chronic hypoxia. A decrease in PGI2, described in patients with different types of $\mathrm{PH}$, may explain pulmonary vasoconstriction, smooth muscle cell proliferation, and enhanced coagulation [30]. However, when tested in a large-scale multicentric clinical trial, synthetic prostanoids significantly worsened survival compared to placebo in a large-scale clinical trial of patients with heart failure with reduced ejection fraction (HFrEF) [40] (Table 1).

Angiopoietin-1 (Ang-1) is an essential factor for lung vascular development [48]. Produced by SMCs and precursor pericytes, Ang-1 stabilizes the development of blood vessels by recruiting muscle cells through migration and division, inducing the creation of mature arterial structures from endothelial tubes. Its receptor, Tie2, is present only on the vascular endothelium. During organ development, the ligand-receptor interactions between smooth-muscle cells and endothelium-specific Tie2, induce the proliferation of muscle cells around the perivascular network [49]. After development, angiopoietin-1 is expressed at a minimally detectable level in the human lung, whereas the Tie2 receptor, believed to regulate vascular maintenance, remains constitutively expressed. An overexpression of Ang-1 with the activation of its receptor has been described in non-familial PH [50]. Moreover, levels of Ang-1 in the lung correlate directly with the severity of pulmonary hypertension in patients, irrespective of the disease [51]. Studies conducted in animal models also support the impact of Ang-1 overexpression on alterations of pulmonary SMCs described in $\mathrm{PH}$ patients [50].

Endothelin-1 (ET-1) is a potent vasoconstrictor widely distributed in the human endothelium with platelet-aggregating properties [52]. In patients with $\mathrm{PH}$, including PH-LHD patients, ET-1 is overexpressed [53]. ET-1 binds to endothelin receptor type A (ETA) and endothelin receptor type B (ETB) expressed mainly on vascular smooth muscle cells (VSMCs) and cardiac myocytes, activating phospholipase $\mathrm{C}$, which generates diacylglycerol and inositol triphosphate. These secondary messengers trigger the release of intracellular calcium, which activates myosin light chain kinase, phosphorylation of myosin light chain, and induce vasoconstriction [30]. ET-1 also activates the RhoA/Rho kinase pathway, which leads to calcium sensitization and sustained vasoconstriction [54]. ETB receptors are expressed on vascular endothelial cells, and upon binding of ET-1, promote production of $\mathrm{NO}$ and prostacyclin, resulting in vasodilation [55]. Unfortunately, potent ET antagonists such as bosentan, darusentan, and macitentan have all shown either neutral or harmful results when specifically tested in the field of PH-LHD [41,42,45,46] (Table 1). 
The ras-homolog family member $\mathrm{A} / \mathrm{Rho}$ associated coiled-coil containing protein kinase (RhoA/ROCK) pathway seems to be specifically implicated in PH-LHD [24,56,57]. ROCKs produce sustained vasoconstriction due to calcium sensitization resulting from their interactions with myosin light chain and myosin phosphatase target subunit-1 [58]. In PH, ROCK activation increases VSMC proliferation, inflammatory cell migration, platelet activation, ROS production, and endothelial dysfunction [58]. In a rat model of PH-LHD, ROCK inhibition with fasudil was shown to increase the pulmonary expression of eNOS, while mitigating PH-LHD, decreasing the medial thickness of the pulmonary artery by $50 \%$, lowering the mPAP by $56 \%$, and reducing the right ventricular hypertrophy by $30 \%$ [59]. Preliminary data from an open label small clinical study suggest that fasudil could also have beneficial hemodynamic effects in patients with heart failure, preserved ejection fraction, and cPC-PH [60].

\subsection{Alterations in Platelet Bioenergetics and Mitochondria Dysregulation}

Mediated by mitochondrial dysfunction, abnormal cell metabolism in multiple tissues contributes to PH both in animal models and in humans PAH [61]. In pulmonary vascular cells, a metabolic switch to aerobic glycolysis confers resistance to apoptosis, cellular hyperproliferation, and vascular remodeling. Under aerobic glycolysis, pulmonary vascular cells also exhibit increased mitochondrial reserve respiratory capacity, which depends on fatty acid oxidation increment and correlates with $\mathrm{PH}$ hemodynamic changes [62]. Moreover, this dysregulation also includes alterations in the pentose phosphate pathway, increases reliance on metabolic activities of HIF- $2 \alpha$ and ROS signaling, and profound alterations in iron metabolism [63]. Thus, dysregulation of mitochondrial metabolism represents a key feature in the pathobiology of $\mathrm{PH}$, at least in $\mathrm{PAH}$. In fact, a comprehensive hypothesis of PAH focuses on the mitochondria as the epicenter of metabolic control and dysregulation, emphasizing the metabolic shift of glycolysis which involves ATP generation, glucose, fatty acids, and ketone bodies [64]. Whether mitochondrial dysregulation takes place in other $\mathrm{PH}$ forms is unknown, as well as the role of the mitochondria in PH-LHD. However, alterations in platelet bioenergetics, a known proxy of mitochondrial function changes, have been recently reported in PH-LHD [65]. These alterations are characterized by an increase in respiratory capacity, similar to PAH subjects, but not by an increase in glycolysis. Further, nitrite has shown no effect on the mitochondrial respiration of platelets [65].

Finally, intracellular lipid chaperones, fatty acid binding proteins (FABPs), coordinate lipid responses in cells and are strongly linked to metabolic and inflammatory pathways [66]. A particular type of FABP, a cardiac-specific cytoplasmic protein, has been reported as a marker for ongoing myocardial damage, with a potential prognostic value of adverse cardiac events. This protein, absent in Group-1 PAH, has been recently proposed as major indicator of PH-LHD [67]. This observation is probably due to the specificity of this molecule for left-heart damage, but also supports distinctive metabolic dysfunctions in PH-LHD.

\subsection{Reactive Oxygen Species}

Reactive oxygen species (ROS) play a major role in $\mathrm{PH}[68,69]$. In fact, pulmonary vascular dysfunction can be promoted by increasing ROS production or decreasing ROS catabolism. In endothelial cells, ROS cause endothelial dysfunction by promoting proliferation, decreasing NO production, and inducing the release of vasoactive mediators. In SMCs, oxidative stress caused by ROS induces contraction and a switch to a synthetic phenotype, characterized by increased VSMC migration and proliferation, hypertrophy, and extracellular matrix protein deposition. These SMC alterations are mediated by an increase of the intracellular free $\mathrm{Ca} 2+$ and a reduction of the expression of contractile phenotypic markers, while enhancing simultaneously the expression of proliferative markers and growth factors. ROS can also trigger the proliferation of fibroblasts. These changes result in vascular remodeling and the development of PH [68]. Additionally, some specific redox changes resulting from oxidation, S-nitrosylation, and S-glutathionylation modulate membrane receptor and 
ion channel activity in PH [70,71]. Ion channels and specifically voltage-gated potassium channels seem to play an important role in the regulation of pulmonary vascular tone, and their inhibition has been described to be involved in PAH [72,73]. To date, these ubiquitous effects of ROS on all three layers of the pulmonary vessels have not been specifically addressed in PH-LHD.

\subsection{Inflammation and Immunity}

Amongst all groups of $\mathrm{PH}$, it seems that PH-LHD has the highest impact on the inflammatory processes and matrix remodeling of the pulmonary vascular tree [67]. The accumulation of mast cells in the lungs of patients with PH-VHD caused by mitral stenosis was described decades ago and was associated with the muscularization of pulmonary vessels [74]. These observations suggested a functional role for mast cells in lung vascular remodeling. Later studies have confirmed immune cell abundance and infiltration in lung vascular lesions and in remodeled vessels [75], not only in Group 1-PAH [76], but also in PH-LHD [77]. These inflammatory changes are followed by stimulation of the adaptive immune system driven by interleukin 6 and signal transducer and activator of transcription 3 (IL6-STAT3) pathway [78]. In fact, in a preclinical rat model of PH-LHD, generated by combining supracoronary aortic banding and chronic inflammation-triggered by metabolic syndrome induction, the relevance of IL6-STAT3 pathway has been recently validated [79]. In a rat model of PH-LHD, mast cells have been shown to induce the release of serotonin and histidine, key role mediators in the vasoconstriction of pulmonary arteries and veins as well as in the proliferation of SMCs by activating the renin-angiotensin system [80]. Mast cells also produce collagen-cleaving matrix metallopeptidase 13 (MMP-13), a platelet-derived growth factor and transforming growth factor that stimulates SMC proliferation [81]. Moreover, mast cells also secrete activin A that promotes the proliferation of SMCs [82].

Recently, the growth differentiation factor 15 (GDF-15) and the soluble urokinase-type plasminogen activator receptor (suPAR), markers of inflammation and involved in the regulation of cell repairmen and growth (Figure 1), have been related to PH-LHD [67]. Unfortunately, the abundance of candidate pathways would require a detailed dissection of signaling events and large human datasets are necessary to identify and validate these and other potential immunological mechanisms involved in PH-LDH [83].

\section{The Genetics of PH-LHD}

Genetic predisposition, environment, and epigenetics are key mechanisms involved in the genesis of $\mathrm{PH}$ (Figure 1). Moreover, the factors responsible for the progression of $\mathrm{PH}$ remain poorly defined. It is believed that in most types of $\mathrm{PH}$, overt disease involves multiple events on a background of genetic predisposition [25].

Most of current knowledge in this area comes again from the field of PAH [84-89]. Variants in bone morphogenetic protein type II receptor (BMPR2) are well-known determinants of PAH severity. The BMPR2 gene encodes the BMPR-II survival regulator of ECs in the pulmonary artery. Mutations on BMPR2 gene (Table 2) lead to a loss of BMPR2 signaling which predisposes to apoptosis of the endothelial cells. This is believed to be the primordial mechanism that initiates PAH [86,90-94]. Although BMPR2 mutations are the most common inherited risk factors for PAH, only the $20 \%$ of carriers develop the disease [95]. Therefore, other genetic (Table 2) and environmental factors such as inflammation must be involved in vascular remodeling [90]. Amongst other genetic factors, mutations in more than 30 genes have been related to Group 1-PAH [84,86,96-99]. In addition to these causal rare sequence variants, disease penetrance and progression has been associated with variants in genetic modifiers [99-104]. A systematic review of genetic mutations in PAH can be found in [86]. 
Table 2. Summary of variants described in major genes associated with pulmonary arterial hypertension (PAH) forms (ClinVar, https://www.ncbi.nlm.nih.gov/clinvar/) (August 2019).

\begin{tabular}{cccccc}
\hline \multicolumn{5}{c}{ Clin Var Classification } \\
\hline Gene & P: Pathogenic & $\begin{array}{c}\text { LP: Likely } \\
\text { Pathogenic }\end{array}$ & $\begin{array}{c}\text { Uncertain } \\
\text { Significance }\end{array}$ & $\begin{array}{c}\text { Benign/Likely } \\
\text { Benign }\end{array}$ & $\begin{array}{c}\text { PH Form (Number of } \\
\text { Causal Variants; P/LP) }\end{array}$ \\
\hline BMPR2 & 405 & 8 & 83 & 70 & PAH (387); PVOD (2); \\
ENG & 187 & 32 & 137 & 62 & PAH-CHD (2) \\
SMAD9 & 37 & 3 & 67 & 63 & PAH (5) \\
CAV1 & 27 & 1 & 6 & 6 & PAH (3) \\
KCNK3 & 17 & 1 & 21 & 6 & PAH (3) \\
ALK1/ACVRL1 & 130 & 30 & 96 & 52 & PAH (7) \\
TBX4 & 23 & 5 & 24 & 32 & PAH-CHD (27); PAH (5) PAH (1) \\
\hline
\end{tabular}

PAH: pulmonary arterial hypertension; PVOD: Pulmonary venoocclusive disease; PAH-CHD: Pulmonary arterial hypertension associated with congenital heart disease; PAH-HHT: Pulmonary arterial hypertension related to hereditary hemorrhagic telangiectasia.

While the genetic background of $\mathrm{PAH}$ has been tested in other $\mathrm{PH}$ forms such as chronic thromboembolic pulmonary hypertension (CTEPH) [105] and hereditary hemorrhagic telangiectasia [106], the genetic variants of PH-LHD have been barely studied [107,108]. It is assumed that BMPR2, ALK1, and other gene variants associated with PAH are only responsible for a minute fraction of patients with PH-LHD [109]. Recently, a genome-wide association study has identified gene variants in NADPH oxidase 3 (NOX3) and TBX4 genes for unclassified non-idiopathic PH in an Eastern Chinese population [110]. Very few studies have been focused on candidate gene/variant analysis in PH-LHD. Due to its absence in the iPC-PH phenotype, a missense variant (rs1799983) in the endothelial NOS (NOS3) gene has been related to pulmonary vascular remodeling in CPC-PH [111]. However, this NOS3 gene variant is a well-known polymorphism that produces an amino acid change from glutamic acid to asparagine with a global minor allele frequency (MAF) of 0.18 and it is currently classified as benign (ClinVar database). A repeat length polymorphism in the promoter region of the serotonin transporter solute carrier family 6 member 4 (SLC6A4, also known as 5-HTT and SERT)) gene has been related to mPAP in heart failure [112]. The SLC6A4 polymorphism (SLC6A4 c.-1941_-1899indel, current annotation) consists of a 43-bp insertion or deletion involving repeat elements that affects protein activity. This variant is classified as pathogenic in ClinVar linked to behavior disorders but the correlation with pulmonary hypertension is unconfirmed [112].

The most encouraging results on the genetics of PH-LHD come from Assad studies $[9,113]$. The authors analyzed pre-existing genotyping data from the Illumina Infinium Human Exome BeadChip in populations with PAH, cPC-PH, and iPC-PH. In addition, they also exploited the Genotype-Tissue Expression (GTEx) database, targeting quantitative trait loci (eQTL) and their underlying genes [9]. Their study reported 141 SNPs that were differentially expressed in PAH and cPC-PH but not in iPC-PH. Amongst them, a missense variant in the collagen type XVIII alpha 1 chain (COL18A1) gene (rs62000962, V661I, MAF $=0.11$, classified as benign in ClinVar) and another missense variant in the mitochondrial elongation factor 2 gene (MIEF2) - also known as SMCR7 (rs12603700, G324E, MAF 0.12, not reported in ClinVar) - have been first putatively associated with PAH [114,115] and recently identified in patients with CPC-PH.

Also, the overrepresentation of lung-relevant functional pathways such as actin binding, extracellular matrix, basement membrane, transferase activity, pre-ribosome structure, and the major histocompatibility complex were also reported. Overall, the study supports the existence of genetic abnormalities in pathways that are highly active in the lungs in patients with PH-LHD, particularly prevalent in CPC-PH. Moreover, the study supports the possibility of common pathophysiological mechanisms between $\mathrm{PAH}$ and $\mathrm{CPC}-\mathrm{PH},[9]$ although none of the genes found genetically altered in $\mathrm{PAH}[86]$ are described in this study. In addition, based on their potential role on inflammatory processes, matrix remodeling and mitochondria dysregulation, some of the main mechanisms specifically involved 
in PH-LHD, those overrepresented genes can reclassified (David database: david.ncifcrf.gov/) as in Table 3, and they could be taken into consideration for further PH-LHD investigations.

Table 3. Reclassification of genes found overrepresented in PAH and cPC-PH vs. iPC-PH [9].

\begin{tabular}{|c|c|}
\hline $\begin{array}{c}\text { Biological Term (GeneOntology, } \\
\text { UniProtKB) }\end{array}$ & $\begin{array}{l}\text { Gene Official Symbol/Function Associated } \\
\text { (www.ncbi.nlm.nih.gov/gene) }\end{array}$ \\
\hline Extracellular matrix & $\begin{array}{l}\text { FREM1/Craniofacial and renal development regulator } \\
\text { COL4A3/Major structural component of basement membranes } \\
\text { COL18A1/Inhibitor of angiogenesis and tumor growth } \\
\text { LAMA5/Noncollagenous basement membrane component } \\
\text { ADAMTS7/Regulator of vascular smooth muscle cell migration }\end{array}$ \\
\hline Immune system/Inflammation & $\begin{array}{l}\text { FREM1 short isoform/Co-receptor of the interleukin } 1 \\
\text { UMODL1/Autoimmune diseases } \\
\text { OR2C3/Immune system regulator } \\
\text { RALY/Ribonucleoprotein involved in autoimmune responses } \\
\text { FPR1/Host defense and inflammation component } \\
\text { DPA1/Class II major histocompatibility complex }\end{array}$ \\
\hline Mitochondrial/Oxidative stress & $\begin{array}{l}\text { CASP2/Regulator of stress-induced signaling pathways } \\
\text { NEK5/Mitochondrial mediated cell death and respiration } \\
\text { SMCR7/Mitochondrial fission machinery component } \\
\text { ZNF3/Oxidative stress response }\end{array}$ \\
\hline
\end{tabular}

\section{The Epigenetics of PH-LHD}

In addition to unknown genetic variants, the variability of PH-LHD may be related to epigenetic changes that regulate the vascular responses. In fact, the role of epigenetic regulation (methylation, histone, and chromatin modifications, and non-coding RNA, e.g., miRNAs, lncRNAs) in PH is being clarified [116]. However, the exact mechanisms involved remain largely unknown. Methylation of the superoxide dismutase-2 (SOD2) gene has been related to PAH [117]. The SOD2 gene encodes for a member of the SOD family that controls the production of endogenous $\mathrm{H}_{2} \mathrm{O}_{2}$, which is a key factor in mitochondrial metabolism [118]. A decrease in SOD2 expression has been shown in PAH patients through a hypermethylation at the enhancer region of intron 2 and promoter region. This epigenetic silencing of SOD2 contributes to the activation of hypoxia-inducible factor 1 and creates a pro-proliferative, apoptosis-resistant state [117]. Moreover, a global DNA methylation and histone acetylation reduction has been described in PH triggered for long-term hypoxia induced by altitude. These epigenetic alterations may lead to SMC proliferation and vessel remodeling in the pulmonary arteries [119]. More recently, a genome-wide DNA methylation study in PAH patients reported a relationship between ATP binding cassette subfamily A member 1 gene (ABCA1) downregulation and lipid metabolism [120]. Additionally, a decrease in granulysin gene (GNLY) demethylation has been described in the blood and lungs in PVOD patients [121]. The role of these mechanisms in PH-LHD remains unclear.

Aberrant histone acetylation-deacetylations have been described in animal PH models and PAH cells [116]. Increased H3 and H4 acetylation of eNOS expression increases the levels of eNOS in pulmonary arterial endothelial cells [122]. Increased expression and activity of class I deacetylases promote the suppression of pro-inflammatory mediators in fibroblasts [123]. Also, a reduction of the mitochondria-localized deacetylase sirtuin 3 gene (SIRT3) expression suppresses mitochondrial function, inhibits apoptosis, and activates several pulmonary hypertension-related transcription factors [124]. Besides, increased expression of a histone methyltransferase, the enhancer of zeste homologue 2, is found in proliferating PASMCs and associated with the progression of PH [125].

More than 10 years ago, non-coding RNA and specifically microRNAs (miRNAs) have been known to be involved in the development and progression of PH [126]. MiRNA are believed to coordinate and regulate multiple disease pathways in the pulmonary vasculature. More than 100 
studies have reported associations between more than 30 miRNAs and different non-Group 2 forms of $\mathrm{PH}$ [127-131]. Amongst them, the most promising results have been identified in PAH: miR-21 [132], miR-17/92 [133], miR-204 [134], miR-130/301 [131], and Let-7d-3p [135]. Very few miRNAs have been specifically investigated in PH-LHD. The miR-204, which is downregulated in SMCs of PAH patients, has not been detected in PH-LHD patients, supporting differences in muscle-specific pathobiology between PAH and PH-LHD [136]. On the contrary, plasma levels of miR-206 do correlate with the clinical worsening of PH-LHD patients [137]. MiR-206 belongs to the miR-1 family, primarily expressed in skeletal muscle. Nevertheless, miR-206 expression has been detected in SMCs of pulmonary arteries and cardiomyocytes. A reduction in miR-206 seems to increase proliferation and reduce apoptosis of SMCs. Although the regulation of miR-206 in PH-LHD remains largely unknown, the reported data supports that miR-206 regulates the cellular features of both cardiomyocytes and SMCs, indirectly suggesting a potentially relevant role in PH-LHD [137]. In addition, based on their role on regulation, enhancement, and/or repressor of different biological pathways, several miRNAs may hypothetically play a role in PH-LHD (Table 4).

Table 4. Top five scored miRNAs predicted to target major genes potentially involved in PH-LHD (miRDB database [138]).

\begin{tabular}{|c|c|c|}
\hline Targeted Gene Symbol & Role in PH-LHD & miRNA Name \\
\hline NOS3 & NOS3 polymorphism in PH-LHD [111] & $\begin{array}{l}\text { miR-154-5p, miR-1303, miR-1206, } \\
\text { miR-377-3p, miR-668-5p }\end{array}$ \\
\hline COL18A1 & SNPs differentially expressed in cPC-PH [9] & $\begin{array}{l}\text { miR-1972, miR-6762-3p, miR-5580-5p, } \\
\text { miR-3118, miR-134-5p }\end{array}$ \\
\hline MIEF2 & SNPs differentially expressed in cPC-PH [9] & $\begin{array}{l}\text { miR-3128, miR-6785-5p, miR-4667-3p, } \\
\text { miR-922, miR-629-5p }\end{array}$ \\
\hline SLC6A4 & $\begin{array}{l}\text { repeat length polymorphism associated to } \\
\text { PH-HF [112] }\end{array}$ & $\begin{array}{l}\text { miR-4775, miR-1250-3p, let-7b-3p }{ }^{1} \\
\text { miR-98-3p, let-7f-1-3p }\end{array}$ \\
\hline RHOA & $\begin{array}{l}\text { RhoA/ROCK pathway specifically involved } \\
\text { in PH-LHD [24] }\end{array}$ & $\begin{array}{l}\text { miR-451b, miR-582-3p, miR-3646, } \\
\text { miR-1207-3p, miR-6815-3p }\end{array}$ \\
\hline ROCK2 & $\begin{array}{l}\text { RhoA/ROCK pathway specifically involved } \\
\text { in PH-LHD [24] }\end{array}$ & $\begin{array}{l}\text { miR-5011-5p, miR-3163, miR-190a-3p, } \\
\text { miR-30d-3p, miR-30e-3p }\end{array}$ \\
\hline EDN1 & $\begin{array}{l}\text { endothelin-1 activates the RhoA/Rho kinase } \\
\text { pathway [54] }\end{array}$ & $\begin{array}{l}\text { miR-7113-3p, miR-4287, miR-651-3p, } \\
\text { miR-671-5p, miR-206 }{ }^{2}\end{array}$ \\
\hline EDNRA & $\begin{array}{l}\text { encodes for endothelin receptor type A; } \\
\text { endothelin- } 1 \text { activates the RhoA/Rho kinase } \\
\text { pathway [54] }\end{array}$ & $\begin{array}{l}\text { miR-148b-3p, miR-335-3p, miR-3671, } \\
\text { miR-3686, miR-607 }\end{array}$ \\
\hline$E D N R B$ & $\begin{array}{l}\text { encodes for endothelin receptor type B; } \\
\text { endothelin- } 1 \text { activates the RhoA/Rho kinase } \\
\text { pathway [54] }\end{array}$ & $\begin{array}{l}\text { miR-30e-5p, miR-19b-2-5p, miR-4282, } \\
\text { miR-19b-1-5p, miR-2052 }\end{array}$ \\
\hline IL6 & $\begin{array}{l}\text { IL6 drives adaptive immune system (mast } \\
\text { cells) in PH-LHD [78] }\end{array}$ & $\begin{array}{l}\text { miR-302d-3p, miR-11181-5p, miR-4256, } \\
\text { miR-196a-1-3p, miR-548c-3p }{ }^{3}\end{array}$ \\
\hline GDF15 & $\begin{array}{l}\text { inflammation markers, correlated with } \\
\text { PH-LHD [67] }\end{array}$ & $\begin{array}{l}\text { miR-499b-5p, miR-6721-5p, miR-1324, } \\
\text { miR-6740-5p, miR-374a-3p }\end{array}$ \\
\hline PLAU & $\begin{array}{l}\text { encodes for suPAR, correlated with } \\
\text { PH-LHD [67] }\end{array}$ & $\begin{array}{l}\text { miR-6131, miR-5692, miR-193a-3p, } \\
\text { miR-193b-3p }{ }^{4}, \text { miR-8485 }\end{array}$ \\
\hline
\end{tabular}

${ }^{1}$ Left-7 miRNA family members are particularly active in CTEPH [139]. ${ }^{2}$ Circulating miR-206 levels correlate with PH-LHD [137]. ${ }^{3}$ Dysregulated in porcine PH shunt model [140]. ${ }^{4}$ Downregulated in the lung and serum of PAH patients and PH rodents [141].

\section{Conclusions}

The prognosis of patients with PH-LHD is close to patients with PAH or even worse. As summarized above, clinical trials testing drugs that are proven to be highly effective in $\mathrm{PAH}$, have shown either harmful or negative results when the drugs are tested in PH-LHD. Therefore, the identification of new therapeutic targets is essential. Based on the current evidence herein described, some novel strategies deserve further investigation. Overexpressing miR-206 would potentially 
suppress EDN1 gene expression, decreasing endothelin-1, which in turn could inhibit ROCK and increase of eNOS pulmonary expression. This could mitigate the VSMC proliferation, inflammatory cell migration, platelet activation, ROS production, and endothelial dysfunction. Testing the potential therapeutic value of this and additional molecular pathways deserves active pre-clinical research in PH-LHD.

Furthermore, due to the well-known limitations of the current functional and hemodynamic criteria, patients with PH-LHD would benefit from a personalized biological stratification of their disease. Both these goals require a comprehensive translational approach that must begin by deciphering the similarities and singularities of PH-LHD and other forms of the disease. Thus far, only limited information regarding the genetic and molecular features of PH-LHD has been exploited. Molecular investigation based on -omics (genomics, transcriptomics, epigenomics, metabolomics, and proteomics) in deeply-phenotyped cohorts may provide important mechanistic information, novel biomarkers and, most importantly, potential therapeutic targets of the disease.

Author Contributions: A.I.F., R.Y. and J.B. collected data and citations and wrote the manuscript. T.M., E.G.-I., A.G.-M., C.P.d.V., P.N.-T., C.C. and P.M.-L. revised and corrected the manuscript and F.F.-A. supervised the manuscript contain.

Funding: Group 2 pulmonary hypertension research is supported by the Instituto de Salud Carlos III (Spain), and the EU_European Regional Development Fund (EC07/90772) as well as by CIBERCV. AIF and PML were financially supported by CIBERCV research contracts. CC was funded by a "Formación de Personal Investigador" Ph.D grant (BES-2017-079924) from the Ministerio de Ciencia e Innovación of Spain.

Acknowledgments: We would like to thank the staff of the Consorcio Centro de Investigación Biomédica en Red, M.P. (CIBER) and the Cardiology Department at the Hospital Universitario Gregorio Marañon for their assistance in all the research in the field of PH-LHD.

Conflicts of Interest: The authors declare no conflict of interest.

\section{References}

1. Hoeper, M.M.; Humbert, M.; Souza, R.; Idrees, M.; Kawut, S.M.; Sliwa-Hahnle, K.; Jing, Z.C.; Gibbs, J.S. A global view of pulmonary hypertension. Lancet Respir. Med. 2016, 4, 306-322. [CrossRef]

2. Choudhary, G.; Jankowich, M.; Wu, W.C. Prevalence and clinical characteristics associated with pulmonary hypertension in African-Americans. PLoS ONE 2013, 8, e84264. [CrossRef] [PubMed]

3. Galie, N.; McLaughlin, V.V.; Rubin, L.J.; Simonneau, G. An overview of the 6th World Symposium on Pulmonary Hypertension. Eur. Respir. J. 2019, 53, 18022148. [CrossRef] [PubMed]

4. Simonneau, G.; Montani, D.; Celermajer, D.S.; Denton, C.P.; Gatzoulis, M.A.; Krowka, M.; Williams, P.G.; Souza, R. Haemodynamic definitions and updated clinical classification of pulmonary hypertension. Eur. Respir. J. 2019, 53, 1801913. [CrossRef] [PubMed]

5. Galie, N.; Humbert, M.; Vachiery, J.L.; Gibbs, S.; Lang, I.; Torbicki, A.; Simonneau, G.; Peacock, A.; Vonk Noordegraaf, A.; Beghetti, M.; et al. 2015 ESC/ERS Guidelines for the diagnosis and treatment of pulmonary hypertension: The Joint Task Force for the Diagnosis and Treatment of Pulmonary Hypertension of the European Society of Cardiology (ESC) and the European Respiratory Society (ERS): Endorsed by: Association for European Paediatric and Congenital Cardiology (AEPC), International Society for Heart and Lung Transplantation (ISHLT). Eur. Heart J. 2016, 37, 67-119. [PubMed]

6. Opitz, C.F.; Hoeper, M.M.; Gibbs, J.S.; Kaemmerer, H.; Pepke-Zaba, J.; Coghlan, J.G.; Scelsi, L.; D'Alto, M.; Olsson, K.M.; Ulrich, S.; et al. Pre-capillary, combined, and post-capillary pulmonary hypertension: A pathophysiological continuum. J. Am. Coll. Cardiol. 2016, 68, 368-378. [CrossRef] [PubMed]

7. Vachiery, J.L.; Tedford, R.J.; Rosenkranz, S.; Palazzini, M.; Lang, I.; Guazzi, M.; Coghlan, G.; Chazova, I.; De Marco, T. Pulmonary hypertension due to left heart disease. Eur. Respir. J. 2019, 53, 1801897. [CrossRef]

8. Wijeratne, D.T.; Lajkosz, K.; Brogly, S.B.; Lougheed, M.D.; Jiang, L.; Housin, A.; Barber, D.; Johnson, A.; Doliszny, K.M.; Archer, S.L. Increasing Incidence and Prevalence of World Health Organization Groups 1 to 4 Pulmonary Hypertension: A Population-Based Cohort Study in Ontario, Canada. Circ. Cardiovasc. Qual. Outcomes 2018, 11, e003973. [CrossRef] 
9. Assad, T.R.; Hemnes, A.R.; Larkin, E.K.; Glazer, A.M.; Xu, M.; Wells, Q.S.; Farber-Eger, E.H.; Sheng, Q.; Shyr, Y.; Harrell, F.E.; et al. Clinical and biological insights into combined post- and pre-capillary pulmonary hypertension. J. Am. Coll. Cardiol. 2016, 68, 2525-2536. [CrossRef]

10. Aris, A.; Camara, M.L. As originally published in 1988: Long-term results of mitral valve surgery in patients with severe pulmonary hypertension. Updated in 1996. Ann. Thorac. Surg. 1996, 61, 1583-1584.

11. Perez del Villar, C.; Martinez-Legazpi, P.; Mombiela, T.; Chazo, C.; Desco, M.; Rodriguez-Perez, D.; Benito, Y.; Barrio, A.; Gutierrez-Ibanes, E.; Del Alamo, J.C.; et al. The natural matching of harmonic responses in the pulmonary circulation. J. Physiol. 2019, 597, 3853-3865. [CrossRef] [PubMed]

12. Humbert, M.; Guignabert, C.; Bonnet, S.; Dorfmuller, P.; Klinger, J.R.; Nicolls, M.R.; Olschewski, A.J.; Pullamsetti, S.S.; Schermuly, R.T.; Stenmark, K.R.; et al. Pathology and pathobiology of pulmonary hypertension: State of the art and research perspectives. Eur. Respir. J. 2019, 53, 1801877. [CrossRef] [PubMed]

13. Barnes, P.J.; Liu, S.F. Regulation of pulmonary vascular tone. Pharmacol. Rev. 1995, 47, 87-131. [PubMed]

14. Snopek, G.; Pogorzelska, H.; Rywik, T.M.; Browarek, A.; Janas, J.; Korewicki, J. Usefulness of endothelin-1 concentration in capillary blood in patients with mitral stenosis as a predictor of regression of pulmonary hypertension after mitral valve replacement or valvuloplasty. Am. J. Cardiol. 2002, 90, 188-189. [CrossRef]

15. Galie, N.; Manes, A.; Dardi, F.; Palazzini, M. Aiming at the appropriate target for the treatment of pulmonary hypertension due to left heart disease. Eur. Heart J. 2018, 39, 1265-1268. [CrossRef]

16. Leopold, J.A. Biological phenotyping of combined post-capillary and pre-capillary pulmonary hypertension: Focus on pulmonary vascular remodeling. J. Am. Coll. Cardiol. 2016, 68, 2537-2539. [CrossRef]

17. Delgado, J.F.; Conde, E.; Sanchez, V.; Lopez-Rios, F.; Gomez-Sanchez, M.A.; Escribano, P.; Sotelo, T.; de la Camara, A.G.; Cortina, J.; de la Calzada, C.S. Pulmonary vascular remodeling in pulmonary hypertension due to chronic heart failure. Eur. J. Heart Fail. 2005, 7, 1011-1016. [CrossRef]

18. Perez Del Villar, C.; Bermejo, J.; Rodriguez-Perez, D.; Martinez-Legazpi, P.; Benito, Y.; Antoranz, J.C.; Desco, M.M.; Ortuno, J.E.; Barrio, A.; Mombiela, T.; et al. The role of elastic restoring forces in right-ventricular filling. Cardiovasc. Res. 2015, 107, 45-55. [CrossRef]

19. Magne, J.; Pibarot, P.; Sengupta, P.P.; Donal, E.; Rosenhek, R.; Lancellotti, P. Pulmonary hypertension in valvular disease: A comprehensive review on pathophysiology to therapy from the HAVEC Group. JACC Cardiovasc. Imaging 2015, 8, 83-99. [CrossRef]

20. Fayyaz, A.U.; Edwards, W.D.; Maleszewski, J.J.; Konik, E.A.; DuBrock, H.M.; Borlaug, B.A.; Frantz, R.P.; Jenkins, S.M.; Redfield, M.M. Global pulmonary vascular remodeling in pulmonary hypertension associated with heart failure and preserved or reduced ejection fraction. Circulation 2018, 137, 1796-1810. [CrossRef]

21. Dayeh, N.R.; Ledoux, J.; Dupuis, J. Lung capillary stress failure and arteriolar remodelling in pulmonary hypertension associated with left heart disease (Group 2 PH). Prog. Cardiovasc. Dis. 2016, 59, 11-21. [CrossRef] [PubMed]

22. Chen, Y.; Guo, H.; Xu, D.; Xu, X.; Wang, H.; Hu, X.; Lu, Z.; Kwak, D.; Xu, Y.; Gunther, R.; et al. Left ventricular failure produces profound lung remodeling and pulmonary hypertension in mice: Heart failure causes severe lung disease. Hypertension 2012, 59, 1170-1178. [CrossRef] [PubMed]

23. Azarbar, S.; Dupuis, J. Lung capillary injury and repair in left heart disease: A new target for therapy? Clin. Sci. 2014, 127, 65-76. [CrossRef] [PubMed]

24. Xiong, P.Y.; Potus, F.; Chan, W.; Archer, S.L. Models and molecular mechanisms of world health organization Group 2 to 4 pulmonary hypertension. Hypertension 2018, 71, 34-55. [CrossRef] [PubMed]

25. Tuder, R.M.; Archer, S.L.; Dorfmuller, P.; Erzurum, S.C.; Guignabert, C.; Michelakis, E.; Rabinovitch, M.; Schermuly, R.; Stenmark, K.R.; Morrell, N.W. Relevant issues in the pathology and pathobiology of pulmonary hypertension. J. Am. Coll. Cardiol. 2013, 62, D4-D12. [CrossRef] [PubMed]

26. Sakao, S.; Tatsumi, K.; Voelkel, N.F. Endothelial cells and pulmonary arterial hypertension: Apoptosis, proliferation, interaction and transdifferentiation. Respir. Res. 2009, 10, 95. [CrossRef] [PubMed]

27. Moraes, D.L.; Colucci, W.S.; Givertz, M.M. Secondary pulmonary hypertension in chronic heart failure: The role of the endothelium in pathophysiology and management. Circulation 2000, 102, 1718-1723. [CrossRef]

28. Ben Driss, A.; Devaux, C.; Henrion, D.; Duriez, M.; Thuillez, C.; Levy, B.I.; Michel, J.B. Hemodynamic stresses induce endothelial dysfunction and remodeling of pulmonary artery in experimental compensated heart failure. Circulation 2000, 101, 2764-2770. [CrossRef] 
29. Sartore, S.; Chiavegato, A.; Faggin, E.; Franch, R.; Puato, M.; Ausoni, S.; Pauletto, P. Contribution of adventitial fibroblasts to neointima formation and vascular remodeling: From innocent bystander to active participant. Circ. Res. 2001, 89, 1111-1121. [CrossRef]

30. Budhiraja, R.; Tuder, R.M.; Hassoun, P.M. Endothelial dysfunction in pulmonary hypertension. Circulation 2004, 109, 159-165. [CrossRef]

31. Palmer, R.M.; Ferrige, A.G.; Moncada, S. Nitric oxide release accounts for the biological activity of endothelium-derived relaxing factor. Nature 1987, 327, 524-526. [CrossRef] [PubMed]

32. Shao, Z.; Wang, Z.; Shrestha, K.; Thakur, A.; Borowski, A.G.; Sweet, W.; Thomas, J.D.; Moravec, C.S.; Hazen, S.L.; Tang, W.H. Pulmonary hypertension associated with advanced systolic heart failure: Dysregulated arginine metabolism and importance of compensatory dimethylarginine dimethylaminohydrolase-1. J. Am. Coll. Cardiol. 2012, 59, 1150-1158. [CrossRef] [PubMed]

33. Ontkean, M.; Gay, R.; Greenberg, B. Diminished endothelium-derived relaxing factor activity in an experimental model of chronic heart failure. Circ. Res. 1991, 69, 1088-1096. [CrossRef] [PubMed]

34. Borlaug, B.A.; Anstrom, K.J.; Lewis, G.D.; Shah, S.J.; Levine, J.A.; Koepp, G.A.; Givertz, M.M.; Felker, G.M.; LeWinter, M.M.; Mann, D.L.; et al. Blood Institute Heart Failure Clinical Research, N. Effect of inorganic nitrite vs placebo on exercise capacity among patients with heart failure with preserved ejection fraction: The INDIE-HFpEF randomized clinical trial. Jama 2018, 320, 1764-1773. [CrossRef] [PubMed]

35. Bermejo, J.; Yotti, R.; Garcia-Orta, R.; Sanchez-Fernandez, P.L.; Castano, M.; Segovia-Cubero, J.; Escribano-Subias, P.; San Roman, J.A.; Borras, X.; Alonso-Gomez, A.; et al. Sildenafil for improving outcomes in patients with corrected valvular heart disease and persistent pulmonary hypertension: A multicenter, double-blind, randomized clinical trial. Eur. Heart J. 2018, 39, 1255-1264. [CrossRef] [PubMed]

36. Redfield, M.M.; Chen, H.H.; Borlaug, B.A.; Semigran, M.J.; Lee, K.L.; Lewis, G.; LeWinter, M.M.; Rouleau, J.L.; Bull, D.A.; Mann, D.L.; et al. Effect of phosphodiesterase-5 inhibition on exercise capacity and clinical status in heart failure with preserved ejection fraction: A randomized clinical trial. Jama 2013, 309, 1268-1277. [CrossRef]

37. Bonderman, D.; Ghio, S.; Felix, S.B.; Ghofrani, H.A.; Michelakis, E.; Mitrovic, V.; Oudiz, R.J.; Boateng, F.; Scalise, A.V.; Roessig, L.; et al. Left Ventricular Systolic Dysfunction Associated With Pulmonary Hypertension Riociguat Trial Study, G., Riociguat for patients with pulmonary hypertension caused by systolic left ventricular dysfunction: A phase IIb double-blind, randomized, placebo-controlled, dose-ranging hemodynamic study. Circulation 2013, 128, 502-511.

38. Gheorghiade, M.; Greene, S.J.; Butler, J.; Filippatos, G.; Lam, C.S.; Maggioni, A.P.; Ponikowski, P.; Shah, S.J.; Solomon, S.D.; Kraigher-Krainer, E.; et al. Investigators, S.-R., Coordinators Effect of vericiguat, a soluble guanylate cyclase stimulator, on natriuretic peptide levels in patients with worsening chronic heart failure and reduced ejection fraction: The SOCRATES-REDUCED randomized trial. Jama 2015, 314, 2251-2262. [CrossRef]

39. Pieske, B.; Maggioni, A.P.; Lam, C.S.P.; Pieske-Kraigher, E.; Filippatos, G.; Butler, J.; Ponikowski, P.; Shah, S.J.; Solomon, S.D.; Scalise, A.V.; et al. Vericiguat in patients with worsening chronic heart failure and preserved ejection fraction: Results of the SOluble guanylate Cyclase stimulatoR in heArT failurE patientS with PRESERVED EF (SOCRATES-PRESERVED) study. Eur. Heart J. 2017, 38, 1119-1127. [CrossRef]

40. Califf, R.M.; Adams, K.F.; McKenna, W.J.; Gheorghiade, M.; Uretsky, B.F.; McNulty, S.E.; Darius, H.; Schulman, K.; Zannad, F.; Handberg-Thurmond, E.; et al. A randomized controlled trial of epoprostenol therapy for severe congestive heart failure: The Flolan International Randomized Survival Trial (FIRST). Am. Heart J. 1997, 134, 44-54. [CrossRef]

41. Luscher, T.F.; Enseleit, F.; Pacher, R.; Mitrovic, V.; Schulze, M.R.; Willenbrock, R.; Dietz, R.; Rousson, V.; Hurlimann, D.; Philipp, S.; et al. Hemodynamic and neurohumoral effects of selective endothelin A (ET(A)) receptor blockade in chronic heart failure: The Heart Failure ET(A) Receptor Blockade Trial (HEAT). Circulation 2002, 106, 2666-2672. [CrossRef] [PubMed]

42. Anand, I.; McMurray, J.; Cohn, J.N.; Konstam, M.A.; Notter, T.; Quitzau, K.; Ruschitzka, F.; Luscher, T.F. Long-term effects of darusentan on left-ventricular remodelling and clinical outcomes in the EndothelinA Receptor Antagonist Trial in Heart Failure (EARTH): Randomised, double-blind, placebo-controlled trial. Lancet 2004, 364, 347-354. [CrossRef] 
43. Packer, M.; McMurray, J.; Massie, B.M.; Caspi, A.; Charlon, V.; Cohen-Solal, A.; Kiowski, W.; Kostuk, W.; Krum, H.; Levine, B.; et al. Clinical effects of endothelin receptor antagonism with bosentan in patients with severe chronic heart failure: Results of a pilot study. J. Card. Fail. 2005, 11, 12-20. [CrossRef] [PubMed]

44. Kaluski, E.; Cotter, G.; Leitman, M.; Milo-Cotter, O.; Krakover, R.; Kobrin, I.; Moriconi, T.; Rainisio, M.; Caspi, A.; Reizin, L.; et al. Clinical and hemodynamic effects of bosentan dose optimization in symptomatic heart failure patients with severe systolic dysfunction, associated with secondary pulmonary hypertension-a multi-center randomized study. Cardiology 2008, 109, 273-280. [CrossRef] [PubMed]

45. Packer, M.; McMurray, J.J.V.; Krum, H.; Kiowski, W.; Massie, B.M.; Caspi, A.; Pratt, C.M.; Petrie, M.C.; DeMets, D.; Kobrin, I.; et al. Investigators Committees Long-term effect of endothelin receptor antagonism with bosentan on the morbidity and mortality of patients with severe chronic heart failure: Primary results of the ENABLE Trials. JACC Heart Fail. 2017, 5, 317-326. [CrossRef] [PubMed]

46. Vachiery, J.L.; Delcroix, M.; Al-Hiti, H.; Efficace, M.; Hutyra, M.; Lack, G.; Papadakis, K.; Rubin, L.J. Macitentan in pulmonary hypertension due to left ventricular dysfunction. Eur. Respir. J. 2018, 51, 1701866. [CrossRef] [PubMed]

47. Sutliff, R.L.; Kang, B.Y.; Hart, C.M. PPARgamma as a potential therapeutic target in pulmonary hypertension. Ther. Adv. Respir. Dis. 2010, 4, 143-160. [CrossRef]

48. Thistlethwaite, P.A.; Lee, S.H.; Du, L.L.; Wolf, P.L.; Sullivan, C.; Pradhan, S.; Deutsch, R.; Jamieson, S.W. Human angiopoietin gene expression is a marker for severity of pulmonary hypertension in patients undergoing pulmonary thromboendarterectomy. J. Thorac. Cardiovasc. Surg. 2001, 122, 65-73. [CrossRef]

49. Sweeney, M.; Foldes, G. It takes two: Endothelial-perivascular cell cross-talk in vascular development and disease. Front. Cardiovasc. Med. 2018, 5, 154. [CrossRef]

50. Richter, M.J.; Tiede, S.L.; Sommer, N.; Schmidt, T.; Seeger, W.; Ghofrani, H.A.; Schermuly, R.; Gall, H. Circulating angiopoietin-1 is not a biomarker of disease severity or prognosis in pulmonary hypertension. PLoS ONE 2016, 11, e0165982. [CrossRef]

51. Du, L.; Sullivan, C.C.; Chu, D.; Cho, A.J.; Kido, M.; Wolf, P.L.; Yuan, J.X.; Deutsch, R.; Jamieson, S.W.; Thistlethwaite, P.A. Signaling molecules in nonfamilial pulmonary hypertension. N. Engl. J. Med. 2003, 348, 500-509. [CrossRef] [PubMed]

52. Attina, T.; Camidge, R.; Newby, D.E.; Webb, D.J. Endothelin antagonism in pulmonary hypertension, heart failure, and beyond. Heart 2005, 91, 825-831. [CrossRef] [PubMed]

53. Meoli, D.F.; Su, Y.R.; Brittain, E.L.; Robbins, I.M.; Hemnes, A.R.; Monahan, K. The transpulmonary ratio of endothelin 1 is elevated in patients with preserved left ventricular ejection fraction and combined pre- and post-capillary pulmonary hypertension. Pulm. Circ. 2018, 8, 2045893217745019. [CrossRef] [PubMed]

54. Yao, L.; Romero, M.J.; Toque, H.A.; Yang, G.; Caldwell, R.B.; Caldwell, R.W. The role of RhoA/Rho kinase pathway in endothelial dysfunction. J. Cardiovasc. Dis. Res. 2010, 1, 165-170. [PubMed]

55. Kowalczyk, A.; Kleniewska, P.; Kolodziejczyk, M.; Skibska, B.; Goraca, A. The role of endothelin-1 and endothelin receptor antagonists in inflammatory response and sepsis. Arch. Immunol. Ther. Exp. 2015, 63, 41-52. [CrossRef]

56. Wang, Q.; Guo, Y.Z.; Zhang, Y.T.; Xue, J.J.; Chen, Z.C.; Cheng, S.Y.; Ou, M.D.; Cheng, K.L.; Zeng, W.J. The effects and mechanism of atorvastatin on pulmonary hypertension due to left heart disease. PLOS ONE 2016, 11, e0157171. [CrossRef]

57. Schmidt, A.; Hall, A. Guanine nucleotide exchange factors for Rho GTPases: Turning on the switch. Genes Dev. 2002, 16, 1587-1609. [CrossRef]

58. Yaoita, N.; Satoh, K.; Shimokawa, H. Novel Therapeutic Targets of Pulmonary Hypertension. Arterioscler. Thromb. Vasc. Biol. 2016, 36, e97-e102. [CrossRef]

59. Dai, Z.K.; Wu, B.N.; Chen, I.C.; Chai, C.Y.; Wu, J.R.; Chou, S.H.; Yeh, J.L.; Chen, I.J.; Tan, M.S. Attenuation of pulmonary hypertension secondary to left ventricular dysfunction in the rat by Rho-kinase inhibitor fasudil. Pediatr. Pulmonol. 2011, 46, 45-59. [CrossRef]

60. Zhang, X.; Zhang, X.; Wang, S.; Luo, J.; Zhao, Z.; Zheng, C.; Shen, J. Effects of Fasudil on Patients with Pulmonary Hypertension Associated with Left Ventricular Heart Failure with Preserved Ejection Fraction: A Prospective Intervention Study. Can. Respir. J. 2018, 2018, 3148259. [CrossRef]

61. Freund-Michel, V.; Khoyrattee, N.; Savineau, J.P.; Muller, B.; Guibert, C. Mitochondria: Roles in pulmonary hypertension. Int. J. Biochem. Cell. Biol. 2014, 55, 93-97. [CrossRef] [PubMed] 
62. Nguyen, Q.L.; Corey, C.; White, P.; Watson, A.; Gladwin, M.T.; Simon, M.A.; Shiva, S. Platelets from pulmonary hypertension patients show increased mitochondrial reserve capacity. JCI Insight 2017, 2, e91415. [CrossRef] [PubMed]

63. Archer, S.L.; Gomberg-Maitland, M.; Maitland, M.L.; Rich, S.; Garcia, J.G.; Weir, E.K. Mitochondrial metabolism, redox signaling, and fusion: A mitochondria-ROS-HIF-1alpha-Kv1.5 O2-sensing pathway at the intersection of pulmonary hypertension and cancer. Am. J. Physiol. Heart Circ. Physiol. 2008, 294, H570-H578. [CrossRef]

64. Tuder, R.M.; Davis, L.A.; Graham, B.B. Targeting energetic metabolism: A new frontier in the pathogenesis and treatment of pulmonary hypertension. Am. J. Respir. Crit. Care Med. 2012, 185, 260-266. [CrossRef] [PubMed]

65. Nguyen, Q.L.; Wang, Y.; Helbling, N.; Simon, M.A.; Shiva, S. Alterations in platelet bioenergetics in Group 2 PH-HFpEF patients. PLoS ONE 2019, 14, e0220490. [CrossRef]

66. Makowski, L.; Hotamisligil, G.S. Fatty acid binding proteins-the evolutionary crossroads of inflammatory and metabolic responses. J. Nutr. 2004, 134, 2464S-2468S. [CrossRef]

67. Mirna, M.; Rohm, I.; Jirak, P.; Wernly, B.; Baz, L.; Paar, V.; Kretzschmar, D.; Hoppe, U.C.; Schulze, P.C.; Lichtenauer, M.; et al. Analysis of novel cardiovascular biomarkers in patients with pulmonary hypertension (PH). Heart Lung Circ. 2019, S1443-9506, 30293-30298. [CrossRef]

68. Aggarwal, S.; Gross, C.M.; Sharma, S.; Fineman, J.R.; Black, S.M. Reactive oxygen species in pulmonary vascular remodeling. Compr. Physiol. 2013, 3, 1011-1034.

69. Zuo, L.; Rose, B.A.; Roberts, W.J.; He, F.; Banes-Berceli, A.K. Molecular characterization of reactive oxygen species in systemic and pulmonary hypertension. Am. J. Hypertens. 2014, 27, 643-650. [CrossRef]

70. Weise-Cross, L.; Resta, T.C.; Jernigan, N.L. Redox regulation of ion channels and receptors in pulmonary hypertension. Antioxid. Redox Signal. 2019, 31, 898-915. [CrossRef]

71. Lambert, M.; Capuano, V.; Olschewski, A.; Sabourin, J.; Nagaraj, C.; Girerd, B.; Weatherald, J.; Humbert, M.; Antigny, F. Ion channels in pulmonary hypertension: A therapeutic interest? Int. J. Mol. Sci. 2018, 19, 3162. [CrossRef] [PubMed]

72. Mandegar, M.; Yuan, J.X. Role of K+ channels in pulmonary hypertension. Vascul. Pharmacol. 2002, 38, 25-33. [CrossRef]

73. McClenaghan, C.; Woo, K.V.; Nichols, C.G. Pulmonary hypertension and ATP-sensitive potassium channels. Hypertension 2019, 74, 14-22. [CrossRef] [PubMed]

74. Heath, D.; Trueman, T.; Sukonthamarn, P. Pulmonary mast cells in mitral stenosis. Cardiovasc. Res. 1969, 3, 467-471. [CrossRef] [PubMed]

75. Kuebler, W.M.; Bonnet, S.; Tabuchi, A. Inflammation and autoimmunity in pulmonary hypertension: Is there a role for endothelial adhesion molecules? (2017 Grover Conference Series). Pulm. Circ. 2018, 8, 2045893218757596. [CrossRef]

76. Savai, R.; Pullamsetti, S.S.; Kolbe, J.; Bieniek, E.; Voswinckel, R.; Fink, L.; Scheed, A.; Ritter, C.; Dahal, B.K.; Vater, A.; et al. Immune and inflammatory cell involvement in the pathology of idiopathic pulmonary arterial hypertension. Am. J. Respir. Crit. Care Med. 2012, 186, 897-908. [CrossRef]

77. Pinto, R.F.; Higuchi Mde, L.; Aiello, V.D. Decreased numbers of T-lymphocytes and predominance of recently recruited macrophages in the walls of peripheral pulmonary arteries from 26 patients with pulmonary hypertension secondary to congenital cardiac shunts. Cardiovasc. Pathol. 2004, 13, 268-275. [CrossRef]

78. Breitling, S.; Hui, Z.; Zabini, D.; Hu, Y.; Hoffmann, J.; Goldenberg, N.M.; Tabuchi, A.; Buelow, R.; Dos Santos, C.; Kuebler, W.M. The mast cell-B cell axis in lung vascular remodeling and pulmonary hypertension. Am. J. Physiol. Lung. Cell Mol. Physiol. 2017, 312, L710-L721. [CrossRef]

79. Ranchoux, B.; Nadeau, V.; Bourgeois, A.; Provencher, S.; Tremblay, E.; Omura, J.; Cote, N.; Abu-Alhayja'a, R.; Dumais, V.; Nachbar, R.T.; et al. Metabolic Syndrome Exacerbates Pulmonary Hypertension due to Left Heart Disease. Circ. Res. 2019, 125, 449-466. [CrossRef]

80. Ferreira, A.J.; Shenoy, V.; Yamazato, Y.; Sriramula, S.; Francis, J.; Yuan, L.; Castellano, R.K.; Ostrov, D.A.; Oh, S.P.; Katovich, M.J.; et al. Evidence for angiotensin-converting enzyme 2 as a therapeutic target for the prevention of pulmonary hypertension. Am. J. Respir. Crit. Care Med. 2009, 179, 1048-1054. [CrossRef]

81. Maxova, H.; Novotna, J.; Vajner, L.; Tomasova, H.; Vytasek, R.; Vizek, M.; Bacakova, L.; Valouskova, V.; Eliasova, T.; Herget, J. In vitro hypoxia increases production of matrix metalloproteinases and tryptase in isolated rat lung mast cells. Physiol. Res. 2008, 57, 903-910. [PubMed] 
82. Cho, S.H.; Yao, Z.; Wang, S.W.; Alban, R.F.; Barbers, R.G.; French, S.W.; Oh, C.K. Regulation of activin A expression in mast cells and asthma: Its effect on the proliferation of human airway smooth muscle cells. J. Immunol. 2003, 170, 4045-4052. [CrossRef] [PubMed]

83. Hoffmann, J.; Yin, J.; Kukucka, M.; Yin, N.; Saarikko, I.; Sterner-Kock, A.; Fujii, H.; Leong-Poi, H.; Kuppe, H.; Schermuly, R.T.; et al. Mast cells promote lung vascular remodelling in pulmonary hypertension. Eur. Respir. J. 2011, 37, 1400-1410. [CrossRef] [PubMed]

84. Ma, L.; Chung, W.K. The role of genetics in pulmonary arterial hypertension. J. Pathol. 2017, 241, $273-280$. [CrossRef] [PubMed]

85. Girerd, B.; Lau, E.; Montani, D.; Humbert, M. Genetics of pulmonary hypertension in the clinic. Curr. Opin. Pulm. Med. 2017, 23, 386-391. [CrossRef] [PubMed]

86. Garcia-Rivas, G.; Jerjes-Sanchez, C.; Rodriguez, D.; Garcia-Pelaez, J.; Trevino, V. A systematic review of genetic mutations in pulmonary arterial hypertension. BMC Med. Genet. 2017, 18, 82. [CrossRef]

87. Southgate, L.; Machado, R.D.; Graf, S.; Morrell, N.W. Molecular genetic framework underlying pulmonary arterial hypertension. Nat. Rev. Cardiol. 2019. [CrossRef]

88. Rhodes, C.J.; Batai, K.; Bleda, M.; Haimel, M.; Southgate, L.; Germain, M.; Pauciulo, M.W.; Hadinnapola, C.; Aman, J.; Girerd, B.; et al. Genetic determinants of risk in pulmonary arterial hypertension: International genome-wide association studies and meta-analysis. Lancet Respir. Med. 2019, 7, 227-238. [CrossRef]

89. Morrell, N.W.; Aldred, M.A.; Chung, W.K.; Elliott, C.G.; Nichols, W.C.; Soubrier, F.; Trembath, R.C.; Loyd, J.E. Genetics and genomics of pulmonary arterial hypertension. Eur. Respir. J. 2019, 53, 1801899. [CrossRef]

90. Tian, W.; Jiang, X.; Sung, Y.K.; Shuffle, E.; Wu, T.H.; Kao, P.N.; Tu, A.B.; Dorfmuller, P.; Cao, A.; Wang, L.; et al. Phenotypically-silent bone morphogenetic protein receptor 2 (BMPR2) mutations predispose rats to inflammation-induced pulmonary arterial hypertension by enhancing the risk for neointimal transformation. Circulation 2019. [CrossRef]

91. Andruska, A.; Spiekerkoetter, E. Consequences of BMPR2 deficiency in the pulmonary vasculature and beyond: Contributions to pulmonary arterial hypertension. Int. J. Mol. Sci. 2018, 19, 2499. [CrossRef] [PubMed]

92. Machado, R.D.; Eickelberg, O.; Elliott, C.G.; Geraci, M.W.; Hanaoka, M.; Loyd, J.E.; Newman, J.H.; Phillips, J.A., 3rd; Soubrier, F.; Trembath, R.C.; et al. Genetics and genomics of pulmonary arterial hypertension. J. Am. Coll. Cardiol. 2009, 54, S32-S42. [CrossRef] [PubMed]

93. Machado, R.D.; Pauciulo, M.W.; Thomson, J.R.; Lane, K.B.; Morgan, N.V.; Wheeler, L.; Phillips, J.A., 3rd; Newman, J.; Williams, D.; Galie, N.; et al. BMPR2 haploinsufficiency as the inherited molecular mechanism for primary pulmonary hypertension. Am. J. Hum. Genet. 2001, 68, 92-102. [CrossRef]

94. Austin, E.D.; Loyd, J.E. The genetics of pulmonary arterial hypertension. Circ. Res. 2014, 115, $189-202$. [CrossRef] [PubMed]

95. West, J.; Cogan, J.; Geraci, M.; Robinson, L.; Newman, J.; Phillips, J.A.; Lane, K.; Meyrick, B.; Loyd, J. Gene expression in BMPR2 mutation carriers with and without evidence of pulmonary arterial hypertension suggests pathways relevant to disease penetrance. BMC Med. Genom. 2008, 1, 45. [CrossRef] [PubMed]

96. Gore, B.; Izikki, M.; Mercier, O.; Dewachter, L.; Fadel, E.; Humbert, M.; Dartevelle, P.; Simonneau, G.; Naeije, R.; Lebrin, F.; et al. Key role of the endothelial TGF-beta/ALK1/endoglin signaling pathway in humans and rodents pulmonary hypertension. PLoS ONE 2014, 9, e100310. [CrossRef] [PubMed]

97. Fujiwara, M.; Yagi, H.; Matsuoka, R.; Saji, T. Analysis of genetic mutation and modifier genes in pulmonary arterial hypertension. Nihon Rinsho 2008, 66, 2071-2075.

98. Fujiwara, M.; Yagi, H.; Matsuoka, R.; Akimoto, K.; Furutani, M.; Imamura, S.; Uehara, R.; Nakayama, T.; Takao, A.; Nakazawa, M.; et al. Implications of mutations of activin receptor-like kinase 1 gene (ALK1) in addition to bone morphogenetic protein receptor II gene (BMPR2) in children with pulmonary arterial hypertension. Circ. J. 2008, 72, 127-133. [CrossRef]

99. Navas, P.; Tenorio, J.; Quezada, C.A.; Barrios, E.; Gordo, G.; Arias, P.; Lopez Meseguer, M.; Santos-Lozano, A.; Palomino Doza, J.; Lapunzina, P.; et al. Molecular analysis of BMPR2, TBX4, and KCNK3 and genotype-phenotype correlations in spanish patients and families with idiopathic and hereditary pulmonary arterial hypertension. Rev. Esp. Cardiol. 2016, 69, 1011-1019. [CrossRef]

100. Kanazawa, H.; Okamoto, T.; Hirata, K.; Yoshikawa, J. Deletion polymorphisms in the angiotensin converting enzyme gene are associated with pulmonary hypertension evoked by exercise challenge in patients with chronic obstructive pulmonary disease. Am. J. Respir. Crit. Care Med. 2000, 162, 1235-1238. [CrossRef] 
101. Pousada, G.; Baloira, A.; Vilarino, C.; Cifrian, J.M.; Valverde, D. Novel mutations in BMPR2, ACVRL1 and KCNA5 genes and hemodynamic parameters in patients with pulmonary arterial hypertension. PLoS ONE 2014, 9, e100261. [CrossRef] [PubMed]

102. Machado, R.D.; Koehler, R.; Glissmeyer, E.; Veal, C.; Suntharalingam, J.; Kim, M.; Carlquist, J.; Town, M.; Elliott, C.G.; Hoeper, M.; et al. Genetic association of the serotonin transporter in pulmonary arterial hypertension. Am. J. Respir. Crit. Care Med. 2006, 173, 793-797. [CrossRef] [PubMed]

103. Blanpain, C.; Le Poul, E.; Parma, J.; Knoop, C.; Detheux, M.; Parmentier, M.; Vassart, G.; Abramowicz, M.J. Serotonin 5-HT(2B) receptor loss of function mutation in a patient with fenfluramine-associated primary pulmonary hypertension. Cardiovasc. Res. 2003, 60, 518-528. [CrossRef] [PubMed]

104. Bohnen, M.S.; Ma, L.; Zhu, N.; Qi, H.; McClenaghan, C.; Gonzaga-Jauregui, C.; Dewey, F.E.; Overton, J.D.; Reid, J.G.; Shuldiner, A.R.; et al. Loss-of-function ABCC8 mutations in pulmonary arterial hypertension. Circ. Genom. Precis. Med. 2018, 11, e002087. [CrossRef]

105. Opitz, I.; Kirschner, M.B. Molecular research in chronic thromboembolic pulmonary hypertension. Int. J. Mol. Sci. 2019, 20, 784. [CrossRef]

106. Vorselaars, V.M.M.; Hosman, A.E.; Westermann, C.J.J.; Snijder, R.J.; Mager, J.J.; Goumans, M.-J.; Post, M.C. Pulmonary Arterial Hypertension and Hereditary Haemorrhagic Telangiectasia. Int. J. Mol. Sci. 2018, 19, 3203. [CrossRef]

107. Ulrich, S.; Szamalek-Hoegel, J.; Hersberger, M.; Fischler, M.; Garcia, J.S.; Huber, L.C.; Grunig, E.; Janssen, B.; Speich, R. Sequence variants in BMPR2 and genes involved in the serotonin and nitric oxide pathways in idiopathic pulmonary arterial hypertension and chronic thromboembolic pulmonary hypertension: Relation to clinical parameters and comparison with left heart disease. Respiration 2010, 79, 279-287. [CrossRef]

108. Mehra, P.; Mehta, V.; Sukhija, R.; Sinha, A.K.; Gupta, M.; Girish, M.P.; Aronow, W.S. Pulmonary hypertension in left heart disease. Arch. Med. Sci. 2019, 15, 262-273. [CrossRef]

109. Hemnes, A.R. Using omics to understand and treat pulmonary vascular disease. Front. Med. 2018, 5, 157. [CrossRef]

110. Yin, C.; Li, K.; Yu, Y.; Huang, H.; Yu, Y.; Wang, Z.; Yan, J.; Pu, Y.; Li, Z.; Li, D.; et al. Genome-wide association study identifies loci and candidate genes for non-idiopathic pulmonary hypertension in Eastern Chinese Han population. BMC Pulm. Med. 2018, 18, 158. [CrossRef]

111. Duarte, J.D.; Kansal, M.; Desai, A.A.; Riden, K.; Arwood, M.J.; Yacob, A.A.; Stamos, T.D.; Cavallari, L.H.; Zamanian, R.T.; Shah, S.J.; et al. Endothelial nitric oxide synthase genotype is associated with pulmonary hypertension severity in left heart failure patients. Pulm. Circ. 2018, 8, 2045894018773049. [CrossRef] [PubMed]

112. Olson, T.P.; Snyder, E.M.; Frantz, R.P.; Turner, S.T.; Johnson, B.D. Repeat length polymorphism of the serotonin transporter gene influences pulmonary artery pressure in heart failure. Am. Heart J. 2007, 153, 426-432. [CrossRef] [PubMed]

113. Assad, T.R.; Brittain, E.L.; Wells, Q.S.; Farber-Eger, E.H.; Halliday, S.J.; Doss, L.N.; Xu, M.; Wang, L.; Harrell, F.E.; Yu, C.; et al. Hemodynamic evidence of vascular remodeling in combined post- and precapillary pulmonary hypertension. Pulm. Circ. 2016, 6, 313-321. [CrossRef] [PubMed]

114. Damico, R.; Kolb, T.M.; Valera, L.; Wang, L.; Housten, T.; Tedford, R.J.; Kass, D.A.; Rafaels, N.; Gao, L.; Barnes, K.C.; et al. Serum endostatin is a genetically determined predictor of survival in pulmonary arterial hypertension. Am. J. Respir. Crit. Care Med. 2015, 191, 208-218. [CrossRef] [PubMed]

115. Marsboom, G.; Toth, P.T.; Ryan, J.J.; Hong, Z.; Wu, X.; Fang, Y.H.; Thenappan, T.; Piao, L.; Zhang, H.J.; Pogoriler, J.; et al. Dynamin-related protein 1-mediated mitochondrial mitotic fission permits hyperproliferation of vascular smooth muscle cells and offers a novel therapeutic target in pulmonary hypertension. Circ. Res. 2012, 110, 1484-1497. [CrossRef] [PubMed]

116. Gamen, E.; Seeger, W.; Pullamsetti, S.S. The emerging role of epigenetics in pulmonary hypertension. Eur. Respir. J. 2016, 48, 903-917. [CrossRef]

117. Archer, S.L.; Marsboom, G.; Kim, G.H.; Zhang, H.J.; Toth, P.T.; Svensson, E.C.; Dyck, J.R.; Gomberg-Maitland, M.; Thebaud, B.; Husain, A.N.; et al. Epigenetic attenuation of mitochondrial superoxide dismutase 2 in pulmonary arterial hypertension: A basis for excessive cell proliferation and a new therapeutic target. Circulation 2010, 121, 2661-2671. [CrossRef]

118. Weir, E.K.; Lopez-Barneo, J.; Buckler, K.J.; Archer, S.L. Acute oxygen-sensing mechanisms. N. Engl. J. Med. 2005, 353, 2042-2055. [CrossRef] 
119. Yang, Q.; Lu, Z.; Ramchandran, R.; Longo, L.D.; Raj, J.U. Pulmonary artery smooth muscle cell proliferation and migration in fetal lambs acclimatized to high-altitude long-term hypoxia: Role of histone acetylation. Am. J. Physiol. Lung Cell Mol. Physiol. 2012, 303, L1001-L1010. [CrossRef]

120. Hautefort, A.; Chesne, J.; Preussner, J.; Pullamsetti, S.S.; Tost, J.; Looso, M.; Antigny, F.; Girerd, B.; Riou, M.; Eddahibi, S.; et al. Pulmonary endothelial cell DNA methylation signature in pulmonary arterial hypertension. Oncotarget 2017, 8, 52995-53016. [CrossRef]

121. Perros, F.; Cohen-Kaminsky, S.; Gambaryan, N.; Girerd, B.; Raymond, N.; Klingelschmitt, I.; Huertas, A.; Mercier, O.; Fadel, E.; Simonneau, G.; et al. Cytotoxic cells and granulysin in pulmonary arterial hypertension and pulmonary veno-occlusive disease. Am. J. Respir. Crit. Care Med. 2013, 187, 189-196. [CrossRef] [PubMed]

122. Xu, X.F.; Ma, X.L.; Shen, Z.; Wu, X.L.; Cheng, F.; Du, L.Z. Epigenetic regulation of the endothelial nitric oxide synthase gene in persistent pulmonary hypertension of the newborn rat. J. Hypertens. 2010, 28, 2227-2235. [CrossRef] [PubMed]

123. Li, M.; Riddle, S.R.; Frid, M.G.; El Kasmi, K.C.; McKinsey, T.A.; Sokol, R.J.; Strassheim, D.; Meyrick, B.; Yeager, M.E.; Flockton, A.R.; et al. Emergence of fibroblasts with a proinflammatory epigenetically altered phenotype in severe hypoxic pulmonary hypertension. J. Immunol. 2011, 187, 2711-2722. [CrossRef] [PubMed]

124. Paulin, R.; Dromparis, P.; Sutendra, G.; Gurtu, V.; Zervopoulos, S.; Bowers, L.; Haromy, A.; Webster, L.; Provencher, S.; Bonnet, S.; et al. Sirtuin 3 deficiency is associated with inhibited mitochondrial function and pulmonary arterial hypertension in rodents and humans. Cell Metab. 2014, 20, 827-839. [CrossRef] [PubMed]

125. Aljubran, S.A.; Cox, R., Jr.; Tamarapu Parthasarathy, P.; Kollongod Ramanathan, G.; Rajanbabu, V.; Bao, H.; Mohapatra, S.S.; Lockey, R.; Kolliputi, N. Enhancer of zeste homolog 2 induces pulmonary artery smooth muscle cell proliferation. PLoS ONE 2012, 7, e37712. [CrossRef]

126. Paulin, R.; Courboulin, A.; Barrier, M.; Bonnet, S. From oncoproteins/tumor suppressors to microRNAs, the newest therapeutic targets for pulmonary arterial hypertension. J. Mol. Med. 2011, 89, 1089-1101. [CrossRef] [PubMed]

127. White, K.; Loscalzo, J.; Chan, S.Y. Holding our breath: The emerging and anticipated roles of microRNA in pulmonary hypertension. Pulm. Circ. 2012, 2, 278-290. [CrossRef]

128. Tupayachi Ortiz, M.G.; Krick, S.; Sarmiento Cano, J.P. High-frequency oscillatory ventilation, microRNAs in pulmonary hypertension, and gastric residual volumes. Am. J. Respir. Crit. Care Med. 2013, 188, 508-509. [CrossRef]

129. Wang, Y.; Xue, X.Y.; Liu, Y.X.; Wang, K.F.; Zang, X.F.; Wang, J.; Wang, P.L.; Zhang, J.; Pan, L.; Zhang, S.Y.; et al. Pulmonary arterial hypertension and microRNAs-an ever-growing partnership. Arch. Med. Res. 2013, 44, 483-487. [CrossRef]

130. Miao, C.; Chang, J.; Zhang, G. Recent research progress of microRNAs in hypertension pathogenesis, with a focus on the roles of miRNAs in pulmonary arterial hypertension. Mol. Biol. Rep. 2018, 45, 2883-2896. [CrossRef]

131. Bertero, T.; Handen, A.L.; Chan, S.Y. Factors Associated with Heritable Pulmonary Arterial Hypertension Exert Convergent Actions on the miR-130/301-Vascular Matrix Feedback Loop. Int. J. Mol..Sci. 2018, 19, 2289. [CrossRef]

132. Sarkar, J.; Gou, D.; Turaka, P.; Viktorova, E.; Ramchandran, R.; Raj, J.U. MicroRNA-21 plays a role in hypoxia-mediated pulmonary artery smooth muscle cell proliferation and migration. Am. J. Physiol. Lung Cell Mol. Physiol. 2010, 299, L861-L871. [CrossRef] [PubMed]

133. Brock, M.; Trenkmann, M.; Gay, R.E.; Michel, B.A.; Gay, S.; Fischler, M.; Ulrich, S.; Speich, R.; Huber, L.C. Interleukin- 6 modulates the expression of the bone morphogenic protein receptor type II through a novel STAT3-microRNA cluster 17/92 pathway. Circ. Res. 2009, 104, 1184-1191. [CrossRef] [PubMed]

134. Courboulin, A.; Paulin, R.; Giguere, N.J.; Saksouk, N.; Perreault, T.; Meloche, J.; Paquet, E.R.; Biardel, S.; Provencher, S.; Cote, J.; et al. Role for miR-204 in human pulmonary arterial hypertension. J. Exp. Med. 2011, 208, 535-548. [CrossRef] [PubMed]

135. Izumiya, Y.; Jinnn, M.; Kimura, Y.; Wang, Z.; Onoue, Y.; Hanatani, S.; Araki, S.; Ihn, H.; Ogawa, H. Expression of Let-7 family microRNAs in skin correlates negatively with severity of pulmonary hypertension in patients with systemic scleroderma. Int. J. Cardiol. Heart Vasc. 2015, 8, 98-102. [PubMed] 
136. Estephan, L.E.; Genuardi, M.V.; Kosanovich, C.M.; Risbano, M.G.; Zhang, Y.; Petro, N.; Watson, A.; Al Aaraj, Y.; Sembrat, J.C.; Rojas, M.; et al. Distinct plasma gradients of microRNA-204 in the pulmonary circulation of patients suffering from WHO Groups I and II pulmonary hypertension. Pulm. Circ. 2019, 9, 2045894019840646. [CrossRef]

137. Jin, P.; Gu, W.; Lai, Y.; Zheng, W.; Zhou, Q.; Wu, X. The circulating microRNA-206 level predicts the severity of pulmonary hypertension in patients with left heart diseases. Cell Physiol. Biochem. 2017, 41, 2150-2160. [CrossRef]

138. Liu, W.; Wang, X. Prediction of functional microRNA targets by integrative modeling of microRNA binding and target expression data. Genome Biol. 2019, 20, 18. [CrossRef]

139. Negi, V.; Chan, S.Y. Discerning functional hierarchies of microRNAs in pulmonary hypertension. JCI Insight 2017, 2, e91327. [CrossRef]

140. Rothman, A.; Restrepo, H.; Sarukhanov, V.; Evans, W.N.; Wiencek, R.G., Jr.; Williams, R.; Hamburger, N.; Anderson, K.; Balsara, J.; Mann, D. Assessment of microRNA and gene dysregulation in pulmonary hypertension by endoarterial biopsy. Pulm. Circ. 2017, 7, 455-464. [CrossRef]

141. Sharma, S.; Umar, S.; Potus, F.; Iorga, A.; Wong, G.; Meriwether, D.; Breuils-Bonnet, S.; Mai, D.; Navab, K.; Ross, D.; et al. Apolipoprotein A-I mimetic peptide 4F rescues pulmonary hypertension by inducing microRNA-193-3p. Circulation 2014, 130, 776-785. [CrossRef] [PubMed]

(C) 2019 by the authors. Licensee MDPI, Basel, Switzerland. This article is an open access article distributed under the terms and conditions of the Creative Commons Attribution (CC BY) license (http://creativecommons.org/licenses/by/4.0/). 